\title{
Ultrastructural and sequence characterization of Penaeus vannamei nodavirus (PvNV) from Belize
}

\author{
Kathy F. J. Tang ${ }^{*}$, Carlos R. Pantoja, Rita M. Redman, Solangel A. Navarro, \\ Donald V. Lightner
}

Department of Veterinary Science and Microbiology, University of Arizona, Tucson, Arizona 85721, USA

\begin{abstract}
The Penaeus vannamei nodavirus (PvNV), which causes muscle necrosis in Penaeus vannamei from Belize, was identified in 2005. Infected shrimp show clinical signs of white, opaque lesions in the tail muscle. Under transmission electron microscopy, the infected cells exhibit increases in various organelles, including mitochondria, Golgi stacks, and rough endoplasmic reticulum. Cytoplasmic inclusions containing para-crystalline arrays of virions were visualized. The viral particle is spherical in shape and 19 to $27 \mathrm{~nm}$ in diameter. A cDNA library was constructed from total RNA extracted from infected shrimp. Through nucleotide sequencing from the cDNA clones and northern blot hybridization, the PVNV genome was shown to consist of 2 segments: RNA1 (3111 bp) and RNA2 (1183 bp). RNA1 contains 2 overlapped open reading frames (ORF A and B), which may encode a RNA-dependent RNA polymerase (RdRp) and a B2 protein, respectively. RNA2 contains a single ORF that may encode the viral capsid protein. Sequence analyses showed the presence of 4 RdRp characteristic motifs and 2 conserved domains (RNA-binding B2 protein and viral coat protein) in the $P V N V$ genome. Phylogenetic analysis based on the translated amino acid sequence of the RdRp reveals that $P_{V N V}$ is a member of the genus Alphanodavirus and closely related to Macrobrachium rosenbergii nodavirus $(M r N V)$. In a study investigating potential $P_{V N V}$ vectors, we monitored the presence of $P_{V N V}$ by RT-PCR in seabird feces and various aquatic organisms collected around a shrimp farm in Belize. $P_{V N V}$ was detected in mosquitofish, seabird feces, barnacles, and zooplankton, suggesting that $P_{V N V}$ can be spread via these carriers.
\end{abstract}

KEY WORDS: Penaeus vannamei nodavirus - $P_{V N V} \cdot$ Ultrastructure · Genomic sequencing · Mechanical carriers

Resale or republication not permitted without written consent of the publisher

\section{INTRODUCTION}

The Penaeus vannamei nodavirus $\left(P_{V N V}\right)$ is the causative agent of muscle necrosis observed in $P$. vannamei cultured in Belize (Tang et al. 2007). The infection resulted in $50 \%$ production loss in affected shrimp ponds. The infected shrimp showed clinical signs of white, opaque lesions in the tails. Histological examination revealed multifocal necrosis and hemocytic fibrosis in the skeletal muscle. Cytoplasmic inclusions were found in the lymphoid organ, muscle, and connective tissues. We determined $P V N V$ to be a nodavirus by partially sequencing the capsid proteincoding region of the virus genome (Tang et al. 2007). There are 2 genera in the Nodaviridae family (Schnee- mann et al. 2005): Alphanodavirus, which primarily infects insects, and Betanodavirus, which infects fishes. The PVNV sequence is similar that of Macrobrachium rosenbergii nodavirus ( $\mathrm{MrNV}$ ) an alphanodavirus which infects the freshwater prawn M. rosenbergii (Bonami et al. 2005), so PVNV is also presumed to be an alphanodovirus.

Nodaviruses are small, non-enveloped, icosahedral viruses approximately 25 to $33 \mathrm{~nm}$ in diameter (Munday \& Nakai 1997, Schneemann et al. 2005). Nodaviruses have a genome of around $4.5 \mathrm{~kb}$ consisting of 2 molecules of positive-sense, single-stranded (ss) RNA: RNA-1 (3.1 kb) and RNA-2 (1.4 kb). Infected cells also contain a third ssRNA (RNA3), which is not packaged within the virion. RNA1 encodes the viral 
RNA-dependent RNA polymerase (RdRp), and RNA2 encodes the capsid protein. RNA3 encodes 1 or 2 small proteins (designated B1 and B2). The function of B1 is not known, but B2 is a double-stranded RNA-binding protein described in other nodaviruses, such as Flock House virus (FHV) and Greasy grouper nervous necrosis virus (GGNNV), to act as a suppressor against host antiviral RNA-silencing response (Li et al. 2002, Lingel et al. 2005, Fenner et al. 2006). However, whether the B2 of PvNV functions similarly in the shrimp cells is not yet known.

In the present study, we examined the morphogenesis of $P V N V$ under transmission electron microscopy (TEM), sequenced its genome (both RNA1 and RNA2), and determined the taxonomic status of the virus. In addition, we investigated potential carriers of $P V N V$ collected from shrimp ponds.

\section{MATERIALS AND METHODS}

PVNV-infected shrimp. Shrimp taxonomy was according to Holthius (1980). The PvNV-infected Penaeus vannamei used in this study were generated by laboratory infection from an isolate obtained from a farm in Belize in 2005. The preparation of inoculum and laboratory infection procedure were described by Tang et al (2007).

Electron microscopy study. Laboratory-infected shrimp were sampled for electron microscopy study; they were preserved in $6 \%$ phosphate-buffered glutaraldehyde and processed for examination as described in Bonami et al. (1992). Electron microscopic observation was performed at $80 \mathrm{kV}$ with a Philips CM12 electron microscope.

RNA extraction, cDNA synthesis and sequence analysis. Hemolymph samples were drawn from the infected shrimp, and subjected to RNA extraction with TRIzol LS (Invitrogen). The RNA was used for construction of a cDNA library (Tang et al. 2007). Each clone was amplified with PCR primers M13F/R (sequences are described in Tang et al. 2005). PCR amplicons were purified and sequenced at the University of Arizona. The nucleotide sequences of RNA1 (larger segment of PvNV genome, GenBank no. HQ259079) and RNA2 (GenBank no. EF137180) were determined by assembling overlapped clones. The determinations of protein molecular mass and isoelectric point (pI) were performed with the European molecular biology open software suite program (EMBOSS) (Rice et al. 2000). The search for open reading frames (ORFs) and conserved domains was performed at the NCBI website (MarchlerBauer \& Bryant 2004, Marchler-Bauer et al. 2009).

The amino acid sequence of the PVNV RNAdependent RNA polymerase (encoded by ORF A within the RNA1) was used to construct a phylogenetic tree with 17 other nodaviruses (see Table 1). Following multiple sequence alignment, a neighborjoining phylogenetic tree was constructed (Saitou \& Nei 1987). The data were re-sampled by 1000 bootstrap replicates to determine the confidence indices within the tree.

Probe labeling and northern blot hybridization. Two probes were labeled, one probe ( $P v N V-190)$ was from a clone containing a $1.7 \mathrm{~kb}$ insert (see Fig. 2A for probe target regions within the RNA1). Another probe $(P V N V-4)$ targets the RNA2 region and was described in Tang et al (2007). These 2 gene probes were labeled with digoxigenin-11-dUTP (Roche) by PCR.

Total RNA extracted from hemolymph were separated in a $1 \%$ formaldehyde gel. After transferring the RNA to a nylon membrane, the membrane was hybridized with both PVNV-190 and PvNV-4. After washes, the membrane was incubated with an anti-digoxigenin antibody conjugated to alkaline phosphatase (Roche) and then visualized using nitroblue tetrazolium and 5-bromo-4chloro-3-indolyl phosphate.

Investigation of $\boldsymbol{P V N V}$ carriers by RT-PCR. Aquatic organisms and seabird feces were sampled from a farm in Belize in 2008. The samples included wild shrimp (3 pooled samples, unknown species), barnacles (3 pooled samples, Cirripedia), mangrove crabs (1 pooled sample, unknown species), mosquitofish (1 pooled sample, Gambusia spp.), zooplankton (3 pooled samples), and Penaeus vannamei broodstock (10 individual shrimp). Total RNA was extracted from each sample using a High-Pure RNA extraction kit (Roche). The rTth DNA polymerase (Applied Biosystems) was used for the first-step RT-PCR detection. The extracted RNA was reverse transcribed at $60^{\circ} \mathrm{C}$ for $30 \mathrm{~min}$, and the PCR was initiated at $94^{\circ} \mathrm{C}$ for $2 \mathrm{~min}$, followed by 40 cycles of $94^{\circ} \mathrm{C}$ for $15 \mathrm{~s}, 60^{\circ} \mathrm{C}$ for $1 \mathrm{~min}$, ending with $60^{\circ} \mathrm{C}$ for $5 \mathrm{~min}$. The sequence of RT-PCR primers (outer primers: $P V N$ N339F/R; inner primers: $P_{V N V} 246 \mathrm{NF} / \mathrm{R}$ ) and nested PCR procedure are described by Tang et al. (2007).

To determine if the replicative intermediate of $P V N V$ was present in the barnacles, the extracted RNA was denatured at $100^{\circ} \mathrm{C}$ for $3 \mathrm{~min}$, chilled on ice, then subjected to reverse transcription with one primer, either PVNV339F (will anneal to negative-strand RNA) or PVNV339R (will anneal to positive-strand RNA). The reaction was carried out at $45^{\circ} \mathrm{C}$ for $30 \mathrm{~min}$ with the SuperScript III reverse transcriptase (Invitrogen). The cDNA was then amplified with the inner primers PVNV246F/R. The PCR reaction was initiated at $94^{\circ} \mathrm{C}$ for $5 \mathrm{~min}$, followed by 40 cycles of $94^{\circ} \mathrm{C}$ for $15 \mathrm{~s}, 60^{\circ} \mathrm{C}$ for $30 \mathrm{~s}$, and $72^{\circ} \mathrm{C}$ for $30 \mathrm{~s}$, ending with $72^{\circ} \mathrm{C}$ for $7 \mathrm{~min}$. An aliquot of the PCR product was analyzed by $1.5 \%$ agarose gel electrophoresis. 


\section{RESULTS}

\section{Morphogenesis of $P v N V$ in the infected cells}

Examination of the PVNV-infected shrimp tissues via TEM revealed the presence of intracytoplasmic inclusions within the cells of the lymphoid organ and of necrotic skeletal muscle. The lymphoid organ tissue sections were used for the ultrastructural characterization. During the early stages of virus infection, cells were observed to have increased numbers of organelles, including mitochondria, Golgi stacks, and rough endoplasmic reticulum. Also, the mitochondria in the proximity of the virogenic stroma were enlarged with either disintegrated or empty cristae (Fig. 1A,B). Membrane invaginations, presumably of endoplasmic reticulum, were observed within the viral inclusions. At the later stages of infection, the nucleocapsids were mature and aggregated in a paracystalline array that was surrounded by a well-defined membrane

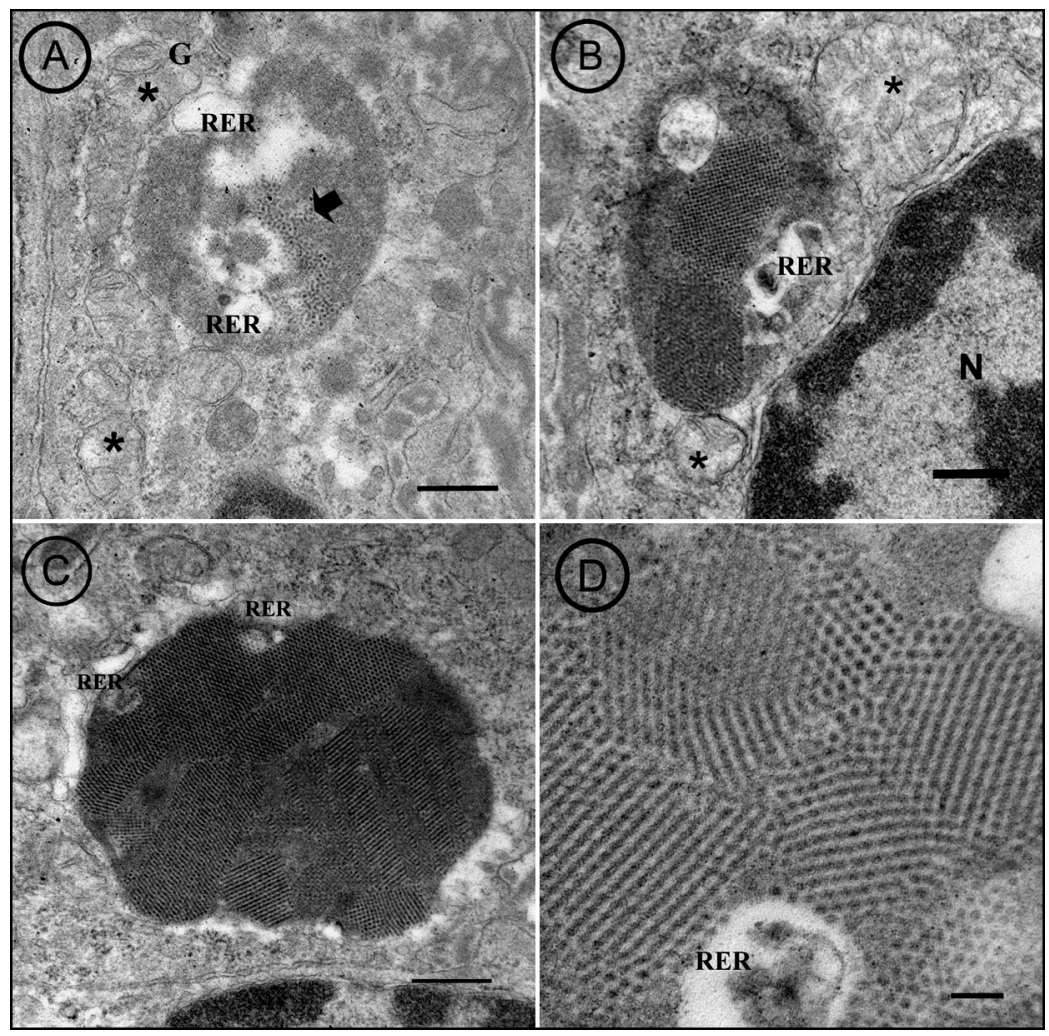

Fig. 1. Penaeus vannamei nodavirus ( $P V N V)$. Transmission electron micrographs of infected lymphoid organ tissue. (A) Viral inclusion showing early accumulation of viral particles (arrow). Several mitochondria (*) can be observed in close proximity. G: Golgi stacks; RER: rough endoplasmic reticulum. (B) Mature viral particles began to form a paracrystalline array. Mitochondria (*) are enlarged. $\mathrm{N}$ : nucleus. (C) Cytoplasmic inclusion in advanced stage of development shows a dense accumulation of viral particles in paracrystalline arrays. (D) High magnification of a viral inclusion shows spherical viral particles. Scale bars $=(A-C)$ $500 \mathrm{~nm}$, (D) $100 \mathrm{~nm}$
(Fig. 1C). The viral particle exhibited spherical in shape with a size ranged from 19 to $27 \mathrm{~nm}$ in diameter (40 virions were measured) (Fig. 1D).

\section{PvNV genomic sequence and analysis}

A cDNA library was constructed from the RNA extracted from the hemolymph of PVNV-infected shrimp, and approximately 120 clones were obtained. From these, we sequenced and analyzed 20 clones using the basic local assignment search tool (BLASTx) program at the NCBI website. We found that 11 clones contained inserts with sequences similar to Macrobrachium rosenbergii nodavirus ( $M r N V)$. These sequences were then assembled into 2 genome segments: RNA1 and RNA2 (Fig. 2A).

The larger genome segment (RNA1) consists of $3111 \mathrm{bp}$ based on sequences assembled from 7 overlapped clones. We analyzed this $3111 \mathrm{bp}$ sequence with the BLASTn program (discontiguous megablast algorithm), and this sequence showed $73 \%$ identity $($ E value $=$ 0.00 ) to the MrNV RNA1 (GenBank no. AY222839). Through an ORF search, RNA1 was found to contain 2 overlapping ORFs. The larger ORF (designated as ORF A, $3102 \mathrm{bp}$, nucleotide no. 7 to 3108, Fig. 2A) may encode a polypeptide of 1033 amino acids (aa) with a molecular mass of $107 \mathrm{kDa}$ and a pI of 8.3. The BLASTp search of this protein revealed that it had an $83 \%$ similarity (E value $=0.00)$ to the $M r N V$ RdRp gene (GenBank no. AAQ54758) and similarities of 40 to $62 \%$ to the RdRp of other nodaviruses (Table 1). The smaller ORF (designated as ORF B, 396 bp, nucleotide no. 2708 to 3103) overlaps with ORF A by a +1 reading frame. ORF B is predicted to encode a polypeptide of 131 aa with a molecular mass of $14 \mathrm{kDa}$ and a pI of 5.2. Through the BLASTp search, the ORF B was found to encode a B2 protein. The PVNV B2 protein is very similar $(79 \%)$ to that of $\mathrm{MrNV}$, and has less similarity (47 to $58 \%$ ) to the B2 protein of 5 other alphanodaviruses including Nodamura virus (NoV), Boolarra virus (BoV), FHV, and Drosophila melanogaster American nodavirus (DmANV).

RNA2 consists of 1183 bp, determined by assembling nucleotide sequences from 4 clones, and contains a 
A

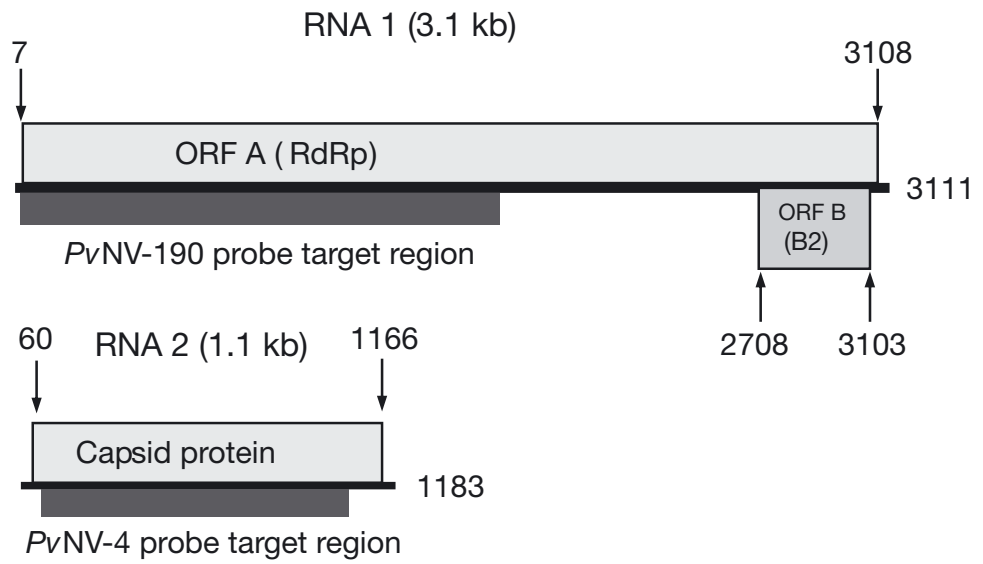

B

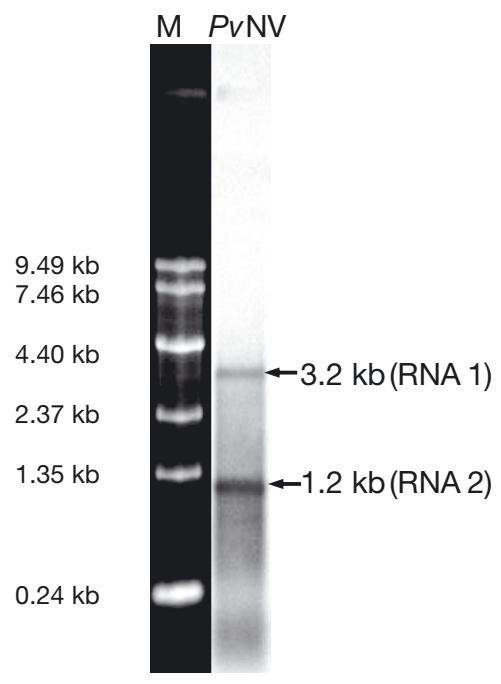

Fig. 2. Penaeus vannamei nodavirus $(P v N V)$. Genomic structure. (A) Schematic representation of RNA1 and RNA2, open reading frames (ORFs) encoding RNA-dependent RNA polymerase (RdRp), B2 protein, and capsid protein. Numbers over the arrows indicate nucleotide positions in the genome. ORFs are boxed with gray. The target regions of 2 probes $(P V N V-190$ and -4 ) are shaded dark grey. (B) Northern blot hybridization showing the presence of 2 RNA segments. Lane M: RNA mol wt markers, lane $P v N V$ : infected shrimp single ORF (1107 bp, nucleotide no. 60 to 1166 (Fig. 2A) that encodes a polypeptide of 368 aa with a molecular weight of $40 \mathrm{kDa}$ and a $\mathrm{pI}$ of 9.5. The BLASTp search of this protein generated a significant $\left(\mathrm{E}\right.$ value $\left.=2 \times 10^{-7}\right)$ match to the capsid protein of $\mathrm{MrNV}$ (GenBank no. ABW38169.1).

To determine the size of RNA1 and RNA2, the total RNA extracted from infected shrimp was analyzed in a denaturing gel containing ethidium bromide. However, no RNA segment was visualized under UV after electrophoresis. However, by northern blot hybridization, 2 segments of RNA at sizes of approximately 3.2 and $1.2 \mathrm{~kb}$ were revealed (Fig. 2B); these are slightly larger than the sizes determined from genomic sequencing (Fig. 2A).

\section{Phylogenetic analysis with viral RdRp gene}

By the phylogenetic analysis based on the amino acid sequence of RdRp, we showed that $P_{V N V}$ clusters with the members of genus Alphanodavirus, and, in particular, it is closely related to a nodavirus, $M r N V$, isolated from the

Table 1. Penaeus vannamei nodavirus $(P v N V)$. Percentage similarity of the amino acid sequence of RNA-dependent RNA polymerase compared to other nodaviruses. N/A: not applicable

\begin{tabular}{|c|c|c|c|c|}
\hline Virus & Abbreviation & $\begin{array}{c}\text { GenBank } \\
\text { no. }\end{array}$ & $\begin{array}{c}\text { No. of } \\
\text { amino acids }\end{array}$ & $\begin{array}{c}\text { Sequence similarity } \\
\text { to } P V N V(\%)\end{array}$ \\
\hline \multicolumn{5}{|l|}{ Alphanodavirus } \\
\hline Penaeus vannamei nodavirus & PVNV & HQ259079 & 1033 & N/A \\
\hline Macrobrachium rosenbergii nodavirus & $\mathrm{MrNV}$ & AAQ54758 & 1045 & 83 \\
\hline Nodamura virus & NoV & NP_077730 & 1043 & 62 \\
\hline Drosophila melanogaster American nodavirus & DmANV & ACU32794 & 998 & 57 \\
\hline Flock House virus & FHV & NP_689444 & 998 & 57 \\
\hline Black beetle virus & BBV & YP_053043 & 998 & 57 \\
\hline Boolarra virus & $\mathrm{BoV}$ & NP_689439 & 998 & 57 \\
\hline Pariacoto virus & $\mathrm{PaV}$ & NP_620109 & 973 & 45 \\
\hline Alphanodavirus HB-2007/CHN & ANV & ADF97523 & 983 & 44 \\
\hline \multicolumn{5}{|l|}{ Betanodavirus } \\
\hline Striped jack nervous necrosis virus & SJNNV & NP_599247 & 983 & 44 \\
\hline Redspotted grouper nervous necrosis virus & RGNNV & ACX69744 & 982 & 43 \\
\hline Japanese flounder nervous necrosis virus & JFNNV & ACN58225 & 982 & 43 \\
\hline Sea bass Iberian betanodavirus & SBNNV & ACX71275 & 982 & 43 \\
\hline Dragon grouper nervous necrosis virus & DGNNV & AAU85148 & 982 & 43 \\
\hline Atlantic cod nodavirus & ACNV & ABR23192 & 981 & 41 \\
\hline Tiger puffer nervous necrosis virus & TPNNV & YP_003288759 & 982 & 41 \\
\hline Barfin flounder nervous necrosis virus & BFNNV & YP_003288756 & 981 & 40 \\
\hline Atlantic halibut nodavirus & AHNV & CAC17792 & 981 & 40 \\
\hline
\end{tabular}


freshwater prawn (Fig. 3). These 2 nodaviruses are grouped with the NoV with a booststrap value of 88 . Comparing the RdRp amino acid sequence, the mean similarities of $P_{V N V}$ to other alphanodaviruses and betanodaviruses are 54 and $42 \%$, respectively.

\section{Sequence motifs and conserved domains in PVNV RdRp, B2 and capsid proteins}

Using a conserved domain search, we showed the RdRp protein encoded by the ORF A to contain a domain (NCBI-curated accession no. cd01699) in the region of amino acid nos. 591 to 740 , with the presence of 4 characteristic motifs as described by Poch et al (1989) (Fig. 4A).

The B2 protein encoded by the ORF B also contains a conserved domain in the region of amino acid no. 15 to 108. This domain has a significant $(E$ value $=9.53 \times$ $10^{-5}$ ) match to members of a B2 protein superfamily (pfam 11473). The sequence alignment of the B2 protein conserved domain of $P V N V$ and other alphanodaviruses is indicated (Fig. 4B).

In the capsid protein, an S (shell) domain (pfam00729: viral coat protein, belongs to the superfamily cl02949) is found in the amino acid nos. 54 to 198. The most conserved region is located at amino acid nos. 54 to 153 ; the search showed an E value of $5.41 \times 10^{-3}$ and matches to 10 other viral coat proteins (Fig. $4 \mathrm{C}$ ).

\section{Studies of the possible vectors for PVNV}

Through an RT-PCR method described by Tang et al. (2007), PVNV was detected in 46 out of 81 (57\%) Penaeus vannamei samples collected during 20062008. With this method, a search for reservoir hosts was also carried out in 2008 through the analysis of samples of a number of species collected from, or in the vicinity of, $P V N V$ shrimp ponds. The samples from species living in the ponds included barnacles, a variety of zooplankton, and the mosquitofish. In addition, we analyzed a seabird feces sample found at the pond sites and several species of wild shrimp and mangrove crabs collected from areas near the ponds. We detected $P V N V$ in all samples except for those of the wild shrimp and mangrove crabs (Fig. 5). In addition, 3 out of $10 P$. vannamei broodstock cultured were positive for $P V N V$.

The primers $P V N V 339 F / R$ were used in a RT-PCR reaction to determine if the $P V N V$ was replicating in the barnacles; the results showed that only $P_{V N V}$ 339R annealed to the RNA (extracted from samples of Lanes 8 and 17 in Fig. 5) and initiated the cDNA synthesis for the subsequent $\mathrm{PCR}$ reaction to generate the

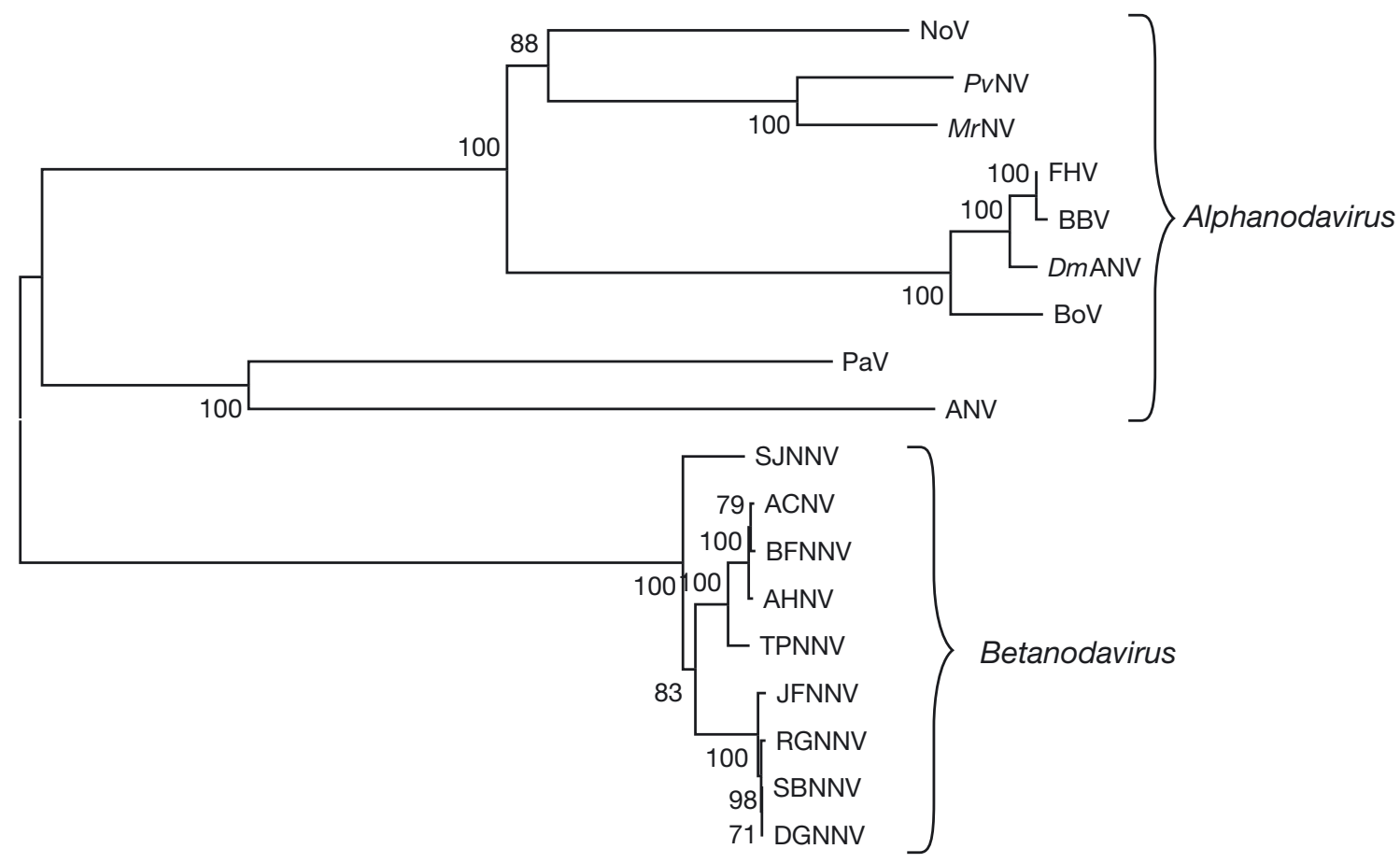

Fig. 3. Penaeus vannamei nodavirus (PvNV). Phylogenetic tree based on the RNA-dependent RNA polymerase amino acid sequence, generated by the neighbor-joining method using the MEGA program; numbers indicate percentages of bootstrap support from replicates. For virus abbreviations see Table 1 
A Sequence motifs within the RNA-dependent RNA polymerase

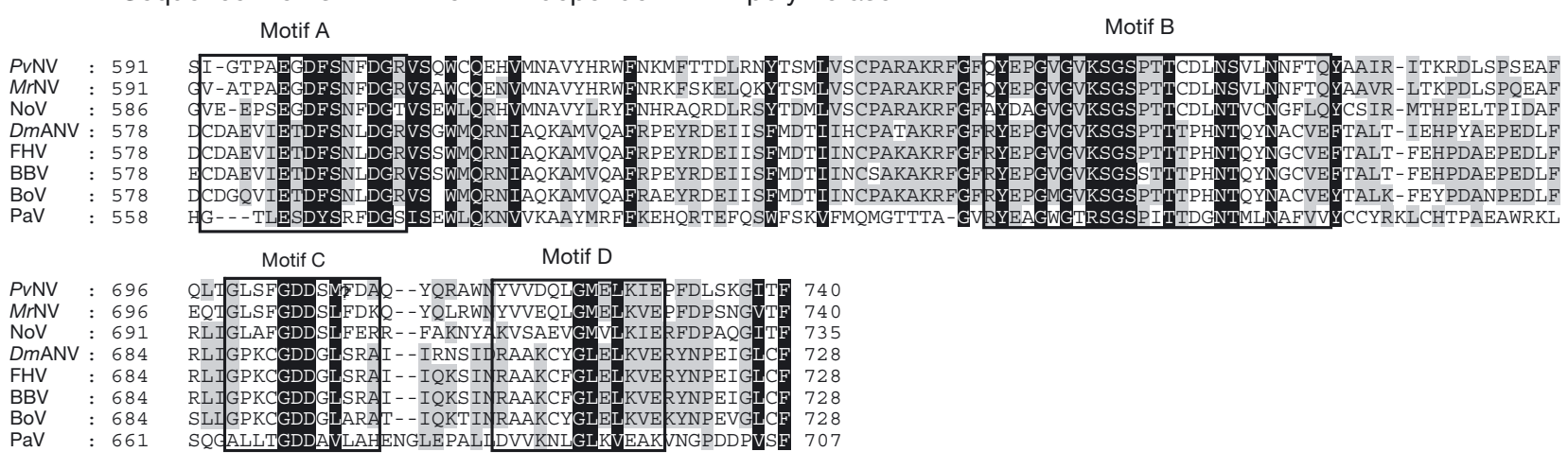

B Conserved domain of the B2 protein

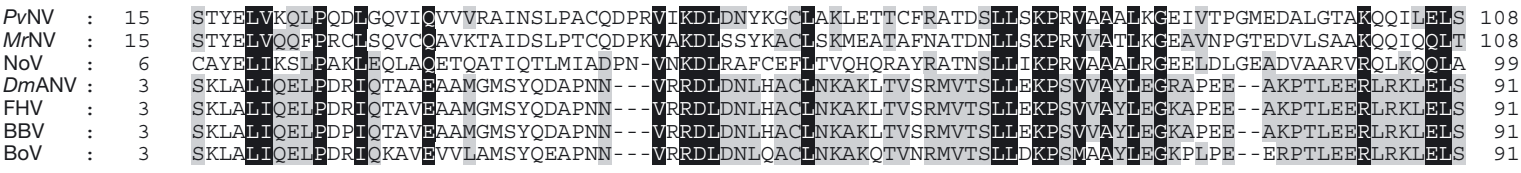

C Conserved domain of the viral capsid protein

\begin{tabular}{|c|c|c|c|c|c|}
\hline NV & $: 54$ & 6) SDFLTSVVAKAS ( & 2) & IDPLD & 1 \\
\hline rNY & $: 51$ & TTVKVRGS & $\mathrm{L}$ & & 141 \\
\hline SBV_A & $: 50$ & AQGTMVKLRPPML (11) CELSTELAVTVT ( 3 ) T ( 1 & ) ELVMPF & SCPTTTSGAIHMGFQYDMADT & 135 \\
\hline MNSV & $: 79$ & AISRRVAGMKPRF (11) REFIASVLPSSD (10) G (1 & 2) ALFT & מת & 173 \\
\hline RCNMV & $: 34$ & 8) TQLVMSVVGSVQ ( 9$) \mathrm{Q}$ & ) FRLNPS & GRVA & 124 \\
\hline NV & $: 77$ & RKPRF (11) REYVSVLSGTNG (11) N & ) FSINPL (2) FLFP & ( > & 72 \\
\hline CRI & $: 83$ & SKPRF (11) RELVGQFNSSSA ( 9) N & $\mathrm{PA}(2) \mathrm{V}$ & TTETGRVAIYFD & 6 \\
\hline & $: 85$ & KKF (13) & & & \\
\hline TBV_C & $: 86$ & AVTRQLVGSKPKF (12) REYLSQVNNSTG ( 9 & PL (2) TLFS & VAIY & 30 \\
\hline$\overline{C Y}$ & $: 86$ & QLLTGSKPKF (12) REYLSQ̃VNMSTG ( & PL (2) TLFS & $\mathrm{TE}$ & 30 \\
\hline & $: 65$ & (11) SELITTLKKNTD ( & (2) GTFN & & \\
\hline
\end{tabular}

Fig. 4. Penaeus vannamei nodavirus (PVNV). Sequence motifs and conserved domains. (A) Sequence motifs of $P V N V$ RdRp aligned with that of Macrobrachium rosenbergii nodavirus (MrNV) and 6 alphanodaviruses; viruses and GenBank nos. are listed in Table 1. Letters above the sequences indicate the RdRp motifs. (B) Sequence alignment of a conserved domain in the RNAbinding protein, B2. The viruses and GenBank nos. are PVNV (HQ259079), MrNV (NP_919037.1), NoV (NP_077731.1), DmANV (ACU32795), FHV (NP_689446.1), BBV (AAA42746.1), BoV (NP_689440.1). (C) Sequence alignment of the conserved domain of viral coat protein. The viruses and GenBank nos. are PVNV (ABO33432.2), MrNV (ABW38169.1), Southern bean mosaic virus (SBV_A, P19899), Melon necrotic spot virus (MNSV, P22955), Red clover necrotic mosaic virus (RCNMV, P22955), Cucumber necrosis virus (CNV, P15183), Cymbidium ringspot virus (CRV, P17456), Tomato bushy stunt virus (TBV-B, 2TBV-B), Tomato bushy stunt virus, strain cherry (TBV_C, P11689), Artichoke mottled crinkle virus (AMCV, P14836), Turnip crinkle virus (TCV, P06663). Numbers in front and at the end of the sequence indicate the position of amino acid in each viral sequence; numbers in parentheses indicate the number of amino acid residues separating the domain. Positions with a $100 \%$ similarity are highlighted with black; those with a $>60 \%$ similarity are highlighted with gray

246 bp PCR fragments (Fig. 6). No amplification was obtained when primer PVNV339F was used in the RT step. Thus, the replicate intermediate RNA of $P V N V$ were not detected in barnacles. These intermediate RNA can be detected with the infected $P$. vannamei.

\section{DISCUSSION}

We describe here the ultrastructural changes in cells infected with PVNV. These changes showed some similarities with those reported for other nodaviruses, such as mitochondria degeneration, endoplasmic reticulum invagination, and formation of membrane-bound viral inclusions (Grotmol et al. 1999). PVNV viral inclusions were found in close association with mitochondria, suggesting that the replication complexes may also be located in the inner/outer mitochondria membranes, as has been demonstrated in FHV (Miller et al. 2001, Miller \& Ahlquist 2002, van Wynsberghe et al. 2007).

We determined the nucleotide sequence of both RNA1 and RNA2 of PVNV through cDNA cloning. By sequence analysis, we propose that $P V N V$ is a species within the genus Alphanodavirus. The family Nodaviridae is comprised of 2 recognized genera, of which only Alphanodavirus is known from arthropod hosts (Schneemann et al. 2005). Therefore, given the taxonomy of the host together with the phylogenetic tree generated from the RdRp sequence, the inclusion of $P V \mathrm{NV}$ as a species within this genus is supported. 


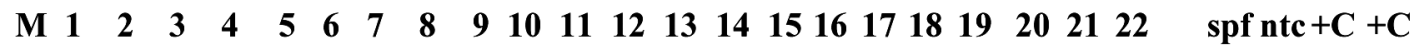

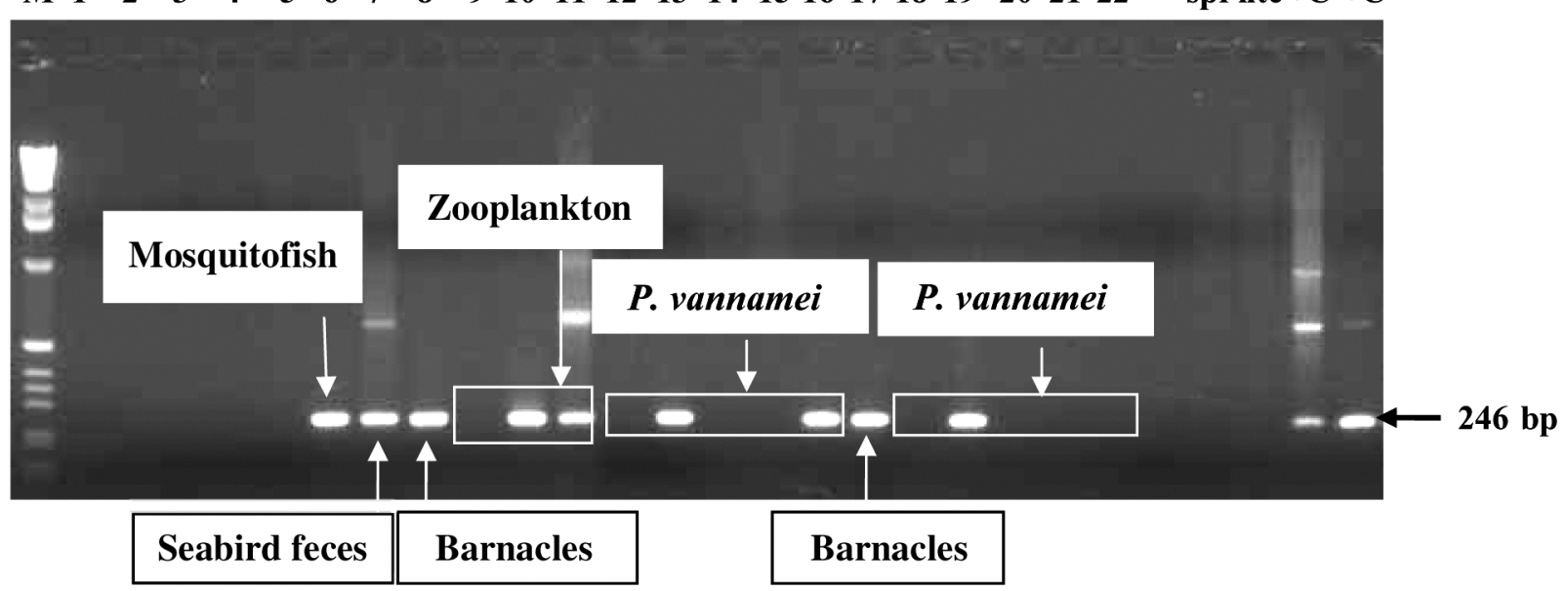

Fig. 5. Peneaus vannamei nodavirus (PVNV). RT-PCR detection in samples collected in a Belize farm during 2008. Lanes 1 to 3: wild shrimp; Lanes 4, 8, 17: barnacles; Lane 5: mangrove crab; Lane 6: mosquitofish; Lane 7: seabird feces; Lanes 9 to 11: zooplankton; Lanes 12 to 16 and 18 to 22: P. vannamei. +C: positive control. M: $1 \mathrm{~kb}$ mol wt markers. The extraneous bands above $246 \mathrm{bp}$ were non-specific products

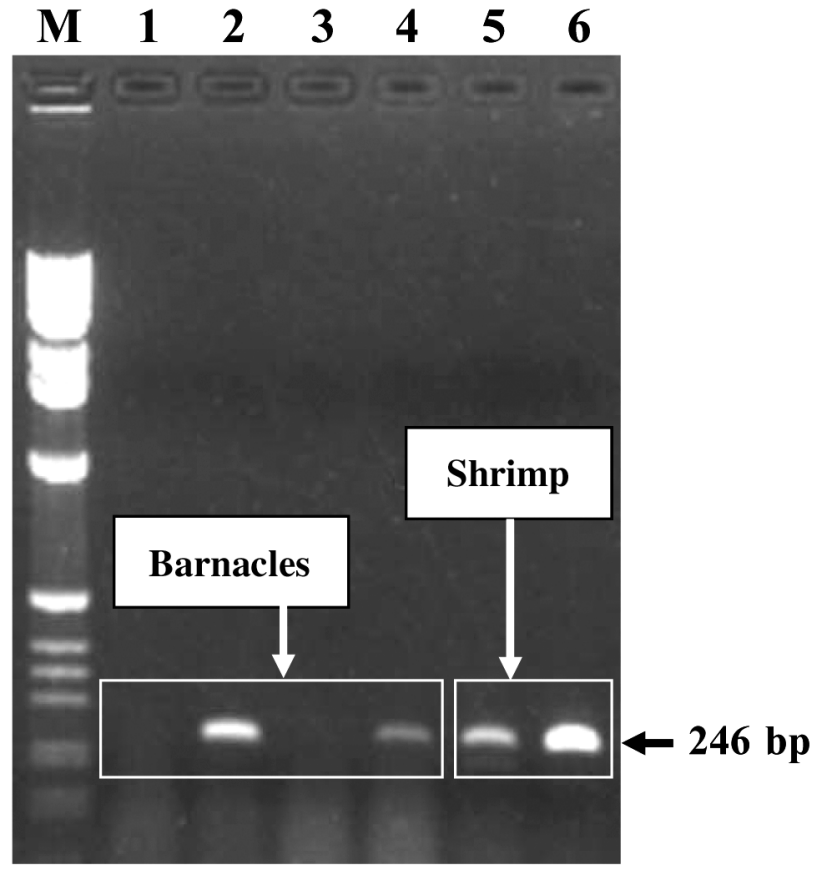

Fig. 6. Peneaus vannamei nodavirus (PVNV). RT-PCR detection of replicative intermediate $P V N V$ RNA. Lanes 1 to 4 : total RNA extracted from barnacles; Lanes 5 and 6: total RNA extracted from PvNV-infected Penaeus vannamei. Lanes 1, 3, and 5: the oligomer $P V N V 339 F$ was used as the primer for the RT reaction; Lanes 2, 4 and 6 the oligomer PVNV339R was used as the primer for the RT reaction. M: $1 \mathrm{~kb}$ mol wt markers

PvNV is most closely related to another freshwater shrimp nodavirus, $M r N V$, with a high (83\%) similarity in the RdRp amino acid sequence. Both $M r N V$ and $P V N V$ were isolated from decapod crustaceans, and neither has been taxonomically classified yet. $M r N V$ contains 2 segments of ssRNA, one of $2.9 \mathrm{~kb}$ and the other of $1.3 \mathrm{~kb}$ (Bonami et al 2005). MrNV is also associated with an extra small (15 $\mathrm{nm}$ in diameter) satellite virus (designated XSV, 796 bp ssRNA) (Qian et al. 2003, Widada \& Bonami 2004). It is not known if there is a XSV-like virus associated with PVNV. Our attempts to purify XSV-type and $P V N V$ virions from infected shrimp were not successful, possibly because we have not been able to obtain heavily infected shrimp in laboratory infections. A rigorous search for a PVNV-related XSV-type virus will require further screening of cDNA clones from infected shrimp.

The gross signs of $M r N V$ and PVNV (a white or opaque tail in infected shrimp) are indistinguishable; however, the 2 nodaviruses differ in virulence. $M r N V$ can cause $100 \%$ mortality in the infected post-larval and juvenile Macrobrachium rosenbergii (Arcier et al. 1999, Sahul Hameed et al. 2004). In contrast, PVNV does not cause mortality in Penaeus vannamei in laboratory infections. In addition, $P V N V$ appears to have a limited host range; it did not infect $M$. rosenbergii in a 4 wk injection bioassay determined by a RT-PCR analysis (K. F. J. Tang unpubl. data). For $M r N V$, several species of marine penaeid shrimp (Penaeus indicus, P. japonicus, and P. monodon) have been identified as reservoir hosts (Sudhakaran et al. 2006). Recently, post-larval $P$. monodon and $P$. indicus, both displaying gross signs of whitish muscle, were found to be infected with $\mathrm{MrNV}$ and XSV by RT-PCR (Ravi et al. 2009).

Investigation of the possible vectors for $P v N V$ showed that this virus can be detected by RT-PCR in seabird feces and crustaceans, such as barnacles and 
zooplankton-organisms that are often associated with shrimp ponds. Both zooplankton and barnacles were filtering nodaviruses that were present in the pond water. With barnacles, through RT-PCR analysis using strand-specific primers, the negative-strand of PvNV RNA was not detected. It is likely the virus is not replicating in the barnacles, so they may only be acting as mechanical carriers. We also carried out histological examination on 10 individual barnacles and did not observe any lesions of muscle necrosis as seen in the $P_{V N V}$-infected shrimp (D. V. Lightner unpubl. data). Seabirds are known to act as mechanical vectors for other shrimp viruses, such as Taura syndrome virus (TSV) and infectious hypodermal and hematopoietic necrosis virus (IHHNV), as the viruses in infected shrimp tissue (that is ingested) are not damaged or inactivated in the digestive tract. Evidence of this is that these viruses detected in seabird feces by PCR (and RT-PCR) were found to be still capable of infecting shrimp in laboratory bioassays (Vanpatten et al. 2004). PVNV is a small, non-enveloped virus with a similar morphology to TSV and IHHNV; therefore, it is likely that $P V N V$ found in the seabird feces in the present study were also infectious. The detection (by RTPCR) of $P V N V$ in the mosquitofish was unexpected, since there have been no reports of natural infections in vertebrates by alphanodaviruses. It is more likely that the mosquitofish ingested virus-carried zooplankton and thus became a mechanical carrier for $P V N V$. All of these carrier hosts can contribute to the spread of pathogenic viruses, and it is difficult to completely exclude them from shrimp farms. The prevalence of various vectors may explain why $P V N V$ has become a major threat to local shrimp farming industries.

Acknowledgements. This work was supported by the Gulf Coast Research Laboratory Consortium Marine Shrimp Farming Program, USDA (grant no. USMSFP2010-21115-UAZ), and a special grant from the National Fisheries Institute. We thank the anonymous shrimp grower in Belize for providing the shrimp and other aquatic organism samples.

\section{LITERATURE CITED}

Arcier JM, Herman F, Lightner DV, Redman RM, Mari J, Bonami JR (1999) A viral disease associated with mortalities in hatchery-reared postlarvae of the giant freshwater prawn Macrobrachium rosenbergii. Dis Aquat Org 38: $177-181$

> Bonami JR, Lightner DV, Redman RM, Poulos BT (1992) Partial characterization of a togavirus (LOVV) associated with histopathological changes of the lymphoid organ of penaeid shrimps. Dis Aquat Org 14:145-152

Bonami JR, Shi Z, Qian D, Sri Widada J (2005) White tail disease of the giant freshwater prawn Macrobrachium rosenbergii: separation of the associated virions and characterization of $M r N V$ as a new type of nodavirus. J Fish Dis 28:23-31
Fenner BJ, Thiagarajan R, Chua HK, Kwang J (2006) Betanodavirus B2 is an RNA interference antagonist that facilitates intracelluar viral RNA accumulation. J Virol 80: 85-94

Grotmol S, Bergh O, Totland GK (1999) Transmission of viral encephalopathy and retinopathy (VER) to yolk-sac larvae of the Atlantic halibut Hippoglossus hippoglossus: occurrence of nodavirus in various organs and possible route of infection. Dis Aquat Org 36:95-106

Holthius LB (1980) Shrimps and prawns of the world: an annotated catalogue of species of interest to fisheries. FAO species catalogue, FAO fisheries Synopsis 125(1). Food and Agriculture Organization of the United Nations, Rome

Li H, Li WX, Ding SW (2002) Induction and suppression of RNA silencing by an animal virus. Science 296:1319-1321

> Lingel A, Simon B, Izaurralde E, Sattler M (2005) The structure of the flock house virus B2 protein, a viral suppressor of RNA interference shows a novel mode of doublestranded RNA recognition. EMBO Rep 6:1149-1155

> Marchler-Bauer A, Bryant SH (2004) CD search: protein domain annotations on the fly. Nucleic Acids Res 32 (Suppl 2):W327-W331

> Marchler-Bauer A, Anderson JB, Chitsaz F, Derbyshire MK, DeWeese-Scott C and others (2009) CDD: specific functional annotation with the Conserved Domain Database. Nucleic Acids Res 37(Suppl 1):D205-D210

> Miller DJ, Ahlquist P (2002) Flock house virus RNA polymerase is a transmembrane protein with amino-terminal sequences sufficient for mitochondrial localization and membrane insertion. J Virol 76:9856-9867

Miller DJ, Schwartz MD, Ahlquist P (2001) Flock house virus RNA replicates on outer mitochondrial membranes in Drosophila cells. J Virol 75:11664-11676

Munday BL, Nakai T (1997) Special topic review: nodaviruses as pathogens in larval and juvenile marine finfish. World $\mathrm{J}$ Microbiol Biotechnol 13:365-381

Poch O, Sauvaget I, Delarue M, Tordo N (1989) Identification of four conserved motifs among the RNA-dependent polymerase encoding elements. EMBO 8:3867-3874

Qian D, Shi Z, Zhang S, Cao Z and others (2003) Extra small virus-like particles (XSV) and nodavirus associated with whitish muscle disease in the giant fresh water prawn Macrobrachium rosenbergii. J Fish Dis 26:521-527

Ravi M, Nazeer Basha A, Sarathi M, Rosa Idalia HH, Sri Widada J, Bonami JR, Sahul Hameed AS (2009) Studies on the occurrence of white tail disease (WTD) caused by MrNV and XSV in hatchery-reared post-lavae of Penaeus indicus and P. monodon. Aquaculture 292:117-120

Rice P, Longden I, Bleasby A (2000) EMBOSS: the European molecular biology open software suite. Trends Genet 16: $276-277$

> Sahul Hameed AS, Yoganandhan K, Sri Widada J, Bonami JR (2004) Studies on the occurrence and RT-PCR detection of Macrobrachium rosenbergii nodavirus and extra small virus-like particles associated with white tail disease of Macrobrachium rosenbergii in India. Aquaculture 238: 127-133

Saitou N, Nei M (1987) The neighbor-joining method: a new method for reconstructing phylogenetic trees. Mol Biol Evol 4:406-425

Schneemann A, Ball LA, Delsert C, Johnson JE, Nishizawa T (2005). Nodaviridae. In: Fauquet CM, Mayo MA, Maniloff J, Desselberger U, Ball LA (eds) Virus taxonomy, 8th Report of the ICTV. Elsevier/Academic Press, London, p 863-870

> Sri Widada J, Bonami JR (2004) Characteristics of the monocistronic genome of extra small virus, a virus-like particle 
associated with Macrobrachium rosenbergii nodavirus: possible candidate for a new species of satellite virus. J Gen Virol 85:643-646

Sudhakaran R, Musthaq SS, Haribabu P, Mukherjee SC, Gopal C, Sahul Hameed AS (2006) Experimental transmission of Macrobrachium rosenbergii nodavirus (MrNV) and extra small virus (XSV) in three species of marine shrimp (Penaeus indicus, Penaeus japonicus and Penaeus monodon). Aquaculture 257:136-141

Tang KFJ, Pantoja CR, Poulos BT, Redman RM, Lightner DV (2005) In situ hybridization demonstrates that Litopenaeus vannamei, L. stylirostris and Penaeus monodon are susceptible to experimental infection with infectious myo-

Editorial responsibility: Grant Stentiford, Weymouth, UK necrosis virus (IMNV). Dis Aquat Org 63:261-265

Tang KFJ, Pantoja CR, Redman RM, Lightner DV (2007) Development of in situ hybridization and RT-PCR assay for the detection of a nodavirus ( $P v N V)$ that causes muscle necrosis in Penaeus vannamei. Dis Aquat Org 75: 183-190

van Wynsberghe PM, Chen HR, Ahlquist P (2007) Nodavirus RNA replication protein A induces membrane association of genomic RNA. J Virol 81:4633-4644

Vanpatten KA, Nunan LM, Lighter DV (2004) Seabirds as potential vectors of penaeid shrimp viruses and the development of a surrogate laboratory model utilizing domestic chickens. Aquaculture 241:31-46

Submitted: October 18, 2010; Accepted: January 11, 2011

Proofs received from author(s): April 19, 2011 